\title{
PENGEMBANGAN MODUL PEMBELAJARAN FISIKA SMA POKOK BAHASAN FLUIDA STATIS BERBASIS POTENSI LOKAL PADA WADUK LECARI BANYUWANGI
}

\author{
Faiqotul Himmah'1), Subiki'1), Supeno'1) \\ 1)Pendidikan Fisika, Fakultas Keguruan dan Ilmu Pendidikan, Universitas Jember, Jember, Jawa Timur, Indonesia \\ Corresponding author : Faiqotul Himmah \\ E-mail : faiqhmh58@gmail.com
}

\section{Diterima 07 November 2021, Direvisi 17 November 2021, Disetujui 18 November 2021}

\begin{abstract}
ABSTRAK
Berdasarkan survei awal yang dilakukan di SMAN 1 Gambiran, media pembelajaran di kelas menggunakan buku ajar konvensional. Beberapa penelitian pada buku ajar menunjukkan adanya miskonsepsi pada penjelasan konsep, penyajian rumus, penulisan simbol, penggunaan satuan, penyajian gambar maupun penyajian soal. Modul merupakan salah satu sarana selain buku ajar yang dapat membantu siswa dalam menghubungkan materi pada kehidupan sehari-hari, susunan modul juga tidak hanya materi saja namun modul juga menyajikan contoh soal, ringkasan, latihan soal, dan tes formatif. Modul dapat digunakan secara mandiri dalam mencapai tujuan pembelajaran, sehingga siswa mampu berkembang dengan sendirinya. Pengimplementasian potensi lokal pada sarana pembelajaran juga layak dikembangkan dan memudahkan siswa untuk memahami materi yang terdapat dalam modul. Penelitian ini menggunakan model pengembangan four- $D$, analisis data yang digunakan terbagi menjadi tiga, yaitu validitas, kepraktisan, dan efektivitas. Teknik analisis data untuk validitas menggunakan analisis deskriptif kuantitatif. Pada efektivitas menggunakan ketuntasan individu dan ketuntasan belajar klasikal. Sedangkan untuk kepraktisan menggunakan analisis skala Likert lima interval secara kuantitatif. Hasil validasi menunjukkan klasifikasi sangat valid dan dapat digunakan sebagai bahan ajar. Hasil respon siswa mendapatkan persentase $75,6 \%$ dengan kriteria praktis. Hasil efektivitas diperoleh dari ketuntasan belajar klasikal yang mencapai $86,67 \%$ dengan kriteria sangat baik. Modul pengembangan dinyatakan valid, praktis dan efektif.
\end{abstract}

Kata kunci: modul; potensi lokal; validitas; kepraktisan; efektivitas.

\begin{abstract}
Based on the initial survey conducted at SMAN 1 Gambiran, the learning media in the classroom uses conventional textbooks. Several studies on textbooks show that there are misconceptions in explaining concepts, presenting formulas, writing symbols, using units, presenting images and presenting questions. The module is a tool other than textbooks that can help students relate material to everyday life. The module arrangement is not only material but also provides sample questions, summaries, practice questions, and formative tests. Modules can be used independently in achieving learning objectives, so that students are able to develop on their own. The implementation of local potential in learning facilities is also worth developing and making it easier for students to understand the material contained in the module. This study uses a four-D development model, the data analysis used is divided into three, namely validity, practicality, and effectiveness. Data analysis techniques for validity using quantitative descriptive analysis. On the effectiveness of using individual mastery and classical learning completeness. As for the practicality of using a Likert scale analysis of five intervals quantitatively. The validation results show the classification is very valid and can be used as teaching materials. The results of student responses get a percentage of $75.6 \%$ with practical criteria. The results of the effectiveness obtained from classical learning completeness which reached $86.67 \%$ with very good criteria. The development module is declared valid, practical and effective.
\end{abstract}

Keywords: module; local potencial; validity; practicality; effectiveness.

\section{PENDAHULUAN}

Sebagai ilmu dasar, fisika memiliki ciri khas yang terbentuk atas konsep, fakta, postulat, hukum, teori, dan prinsip, serta metodologi keilmuan yang kesemuanya mencakup bangun ilmu. Fisika adalah ilmu yang terbentuk melalui prosedur baku atau biasa disebut sebagai metode ilmiah (Mundilarto, 2010). Menurut Undang-Undang Tahun 2003 tentang Sistem Pendidikan 
Nasional, suatu proses yang saling berhubungan antara siswa dengan guru dan sumber belajar pada suatu lingkungan belajar merupakan definisi dari pembelajaran. Mundilarto juga menyatakan bahwa kelahiran fisikawan atau saintis tidaklah dirancang melalui pembelajaran fisika, namun untuk mengakomodasi siswa akan perlunya berpikir kritis terhadap suatu perihal baru yang dijumpainya didasarkan pada ilmu atau wawasan yang telah dipercaya akan kesahihannya. Pembelajaran fisika mengakomodasi siswa dalam meningkatkan kualitas diri menjadi seseorang yang memiliki sikap ilmiah, mampu memproses fenomena dan pengetahuan yang diperoleh, serta mampu memahami kejadian-kejadian yang ada di sekelilingnya bekerja (Mundilarto, 2010).

Buku ajar digunakan oleh mayoritas guru selain untuk pembelajaran di kelas juga digunakan dalam pemberian latihan atau tugas. Buku ajar digunakan untuk menentukan strategi pembelajaran dan menyampaikan materi. Sementara itu siswa menggunakan buku ajar sebagai sumber untuk mendapatkan informasi dalam pengerjaan tugas di sekolah ataupun pekerjaan rumah (Fitrianingrum et al., 2013). Berdasarkan survei awal yang dilakukan di SMAN 1 Gambiran, media pembelajaran di kelas menggunakan buku ajar konvensional. Setiap guru pada semua tingkat pendidikan paling tidak menggunakan satu buku pegangan dalam kegiatan pembelajarannya. Penelitian Sukmawati, dkk di SMAN 1 Bandar Sribhawono, memperlihatkan terdapat distingsi rerata potensi berpikir kritis siswa antara pembelajaran yang menggunakan buku konvensional yang digunakan dengan modul dengan strategi inkuiri terbimbing. Modul yang menggunakan strategi inkuiri terbimbing dibandingkan dengan buku pegangan guru yang biasa dipakai di SMAN 1 Bandar Sribhawono terbukti memberikan andil eskalasi rerata $\mathrm{N}$-gain sebesar 0,618 dengan hasil uji beda sebesar 0,049. Sehingga dapat dikatakan siswa lebih mudah menguasai konsep fluida statis dengan modul yang menggunakan strategi inkuiri terbimbing dibandingkan dengan kelas yang menggunakan buku ajar konvensional (Sukmawati et al., 2016).

Materi fluida ialah salah satu materi fisika yang sukar dipahami, karena karakteristik materi yang bersifat abstrak dan memiliki banyaknya rumus yang harus dihafal. Hal ini ditunjang oleh penelitian Susanti (2013: 227) yang menjelaskan miskonsepsi siswa secara individu dan secara kelompok menggunakan analisis CRI. Konsep yang paling banyak siswa mengalami miskonsepsi adalah konsep asas Bernoulli dan asas kontinuitas, yaitu pada kelas replikasi I sebesar $61,0 \%$ sedangkan pada kelas replikasi II sebesar $52,0 \%$. Alasan penyebab terjadinya miskonsepsi yaitu bersumber dari buku, konteks, guru, cara mengajar dan siswa.

Upaya menumbuhkan motivasi belajar siswa, dan membuat siswa memiliki kreatifitas dan kemampuan untuk memecahkan masalah, salah satu penyelesaiannya adalah dengan mengembangkan bahan ajar berorientasi pada kemampuan berpikir kritis. Selain itu, kesuksesan dalam belajar banyak ditentukan oleh seberapa jauh upaya siswa untuk mencapai kesuksesan tersebut. Brown dan Saks menyatakan upaya belajar siswa memiliki dua dimensi, yakni 1) durasi yang digunakan siswa dalam suatu kegiatan belajar, dan 2) intensitas keterlibatan siswa dalam kegiatan belajar tersebut. Selain dua dimensi yang telah disebutkan, dalam teori Carroll masih terdapat tiga variabel utama dan dua variabel tambahan yang dapat mempengaruhi proses belajar, yang pertama yakni aptitude (bakat), yaitu durasi ideal yang dimiliki siswa untuk mencapai suatu tujuan pendidikan. Variabel kedua yaitu perseverance (ketekunan), jumlah waktu yang benar-benar dipakai siswa untuk belajar. Variabel ketiga yaitu jumlah waktu yang dialokasikan yang disebut opportunity to learn (kesempatan untuk belajar). Dua komponen lainnya adalah kapabilitas siswa dalam memahami pembelajaran (ability to understand instruction), dan mutu pembelajaran itu sendiri (quality of instruction) (Hernawan, 2008).

Modul merupakan satu dari sekian banyaknya sarana selain buku ajar yang membuat siswa lebih mudah dalam menguasai materi yang diberitahukan oleh guru di kelas karena modul dapat mengakomodasi siswa dalam menghubungkan materi dengan kehidupan sehari-hari. Modul adalah salah satu sarana pembelajaran yang menyajikan susunan materi secara sistematis dan utuh, supaya siswa lebih mudah menguasai materi dan terarah dengan yang dijelaskan oleh guru. Selain itu, modul tidak saja tersusun oleh materi akan tetapi modul juga memberikan contoh soal, ringkasan, latihan soal, dan tes formatif. Daryanto mengungkapkan bahwa modul pembelajaran yang dikemas secara sistematis dan utuh sangatlah berguna dalam proses pembelajaran karena di dalamnya berisi seperangkat pengalaman belajar yang terencana dan dirancang untuk mendukung siswa mencapai tujuan pembelajaran khusus, substansi belajar atau materi, dan evaluasi (Daryanto, 2013).

Oemar Hamalik mengungkapkan modul merupakan suatu paket pengajaran yang berkaitan dengan suatu komponen, bertahap 
dari mata pelajaran tertentu. Disebut bertahap karena modul mendalami secara pribadi dari suatu komponen ke komponen yang lain. Pelaksanaan pengajaran modular didasarkan pada pertimbangan-pertimbangan sebagai berikut:

1. Individualisasi belajar, siswa dapat menentukan strategi belajarnya sendiri.

2. Fleksibilitas (Keluwesan), susunan format pelajaran bermacam-macam.

3. Kebebasan, kegiatan belajar mandiri dapat dilakukan oleh siswa.

4. Partisipasi Aktif, mayoritas kegiatan belajar terletak pada keaktifan individu.

5. Peranan pengajar,kegiatan belajarmengajar berbentuk interaksi dengan bahan tertulis dan interaksi yang dapat menunjang lainnya, tidak lagi berbentuk tatap muka.

6. Interaksi di Kalangan Peserta, mayoritas kegiatan belajar dihabiskan dalam interaksi ini, misalnya melalui kegiatan diskusi dan belajar kelompok (Hamalik, 2006).

Tjipto Utomo mengungkapkan bahwa pembelajaran dengan menerapkan modul memperoleh keuntungan sebagai berikut:

a. Motivasi siswa mengalami peningkatan, karena tiap-tiap pengerjaan tugas disekat dengan jelas dan sesuai dengan potensi siswa.

b. Setelah dilakukan evaluasi, guru dan siswa dapat mengetahui pada bagian modul mana siswa telah berhasil dan pada bagian mana siswa belum berhasil.

c. Hasil yang dicapai siswa sesuai dengan pemahamannya.

d. Pemerataan materi pelajaran dalam satu semester.

e. Pendidikan lebih efektif, karena susunan materi pelajaran menurut pada tingkatan akademik (Utomo \& Ruijter, 1991).

Penyusunan modul menurut Sudjana dan Rivai, memiliki langkah-langkah sebagai berikut:

1. Menyusun kerangka modul

Penyusunan kerangka modul terdiri dari beberapa tahapan, yaitu:

(a) Merumuskan atau menetapkan tujuan instruksional dari umum menjadi khusus.

(b) Menyusun butir-butir soal penilaian untuk mengetahui seberapa jauh pencapaian tujuan khusus.

(c) Menentukan substansi materi pelajaran yang sesuai dengan tujuan khusus.

(d) Menyusun substansi materi dalam urutan yang masuk akal.

(e) Memeriksa langkah-langkah kegiatan belajar untuk mencapai seluruh tujuan. (f) Menentukan instrumen yang diperlukan dalam kegiatan belajar dengan modul tersebut.

2. Menulis agenda secara rinci

Agenda pada modul terdiri dari bagianbagian sebagai berikut:

(a) Penyusunan petunjuk guru.

(b) Lembaran kegiatan siswa.

(c) Lembaran kerja siswa.

(d) Lembaran tes.

(e) Lembaran jawaban tes(Sudjana \& Rivai, 2007).

Menurut Rahdiyanta, modul penting untuk diprogram dan dikembangkan dengan mencermati beberapa elemen yang disyaratkan, yaitu: format, organisasi, daya tarik, ukuran huruf, spasi kosong, dan konsistensi dengan tujuan untuk mewujudkan modul pembelajaran yang dapat memerankan fungsi dan perannya dalam pembelajaran yang efektif (Depdiknas, 2008).

Pada era globalisasi seperti sekarang ini, produk dan budaya asing merambah dan berkembang sangat pesat dalam kehidupan bangsa. Untuk mengatasi degradasi ini tentunya pendidikan sangatlah memiliki peranan penting. Pengimplementasian potensi lokal dalam sarana pembelajaran diharapkan lebih meningkatkan hasil belajar siswa serta dapat melestarikan potensi lokal itu sendiri. Upaya melestarikan potensi lokal pada daerah, pemerintah telah melakukan langkah nyata melalui bidang pendidikan. Bermula dengan diterapkannya Kurikulum Tingkat Satuan Pendidikan (KTSP), satuan pendidikan diberikan kewenangan untuk memaksimalkan potensi yang dimiliki oleh tiap-tiap daerah. Pernyataan ini membuat perkembangan kurikulum di seluruh satuan pendidikan di Indonesia terdampak untuk menyelaraskan dengan potensi yang dimiliki pada setiap daerah.

Kondisi ini selaras dengan Peraturan Pemerintah No.19 Tahun 2005 tentang Standar Nasional Pendidikan pasal 17 ayat 1 yang menyebutkan bahwa: "Kurikulum tingkat satuan Pendidikan SD/MI/SDLB, SMP/MTs/SMPLB, SMA/MA/SMALB, SMK/MAK, atau bentuk lain yang sederajat dikembangkan sesuai dengan satuan Pendidikan, potensi daerah/karakteristik daerah, sosial budaya masyarakat setempat, dan peserta didik". Masing-masing daerah memiliki identitas dan kekhasan yang menjadi keunggulannya. Potensi lokal memiliki beberapa karakteristik yaitu: a) terdapat pada wilayah suatu masyarakat, b) rasa kepemilikan oleh masyarakat, c) menyatu dengan alam, d) bersifat global, e) berdaya guna, f) mudah dimengerti dengan menggunakan common 
sense, g) merupakan peninggalan turun temurun (Saway, 2004).

Studi yang dilakukan oleh (Agustin et al., 2018), yaitu mengembangkan modul fisika berbasis potensi lokal untuk pelajar SMA. Dari hasil kajian dikatakan bahwa modul fisika berbasis potensi lokal dikategorikan patut untuk dikembangkan dan memberikan kemudahan kepada siswa untuk memahami materi yang dipresentasikan melalui modul, hal ini terbukti dalam pembelajaran menghasilkan sebanyak $50 \%$ siswa menjadi lebih mudah untuk mengasosiasikan konsep mata pelajaran dengan kehidupan sehari-hari. Berdasarkan uraian pendekatan potensi lokal dalam upaya menciptakan pembelajaran kontekstual dan bahan ajar yang inovatif, pendekatan ini dapat diterapkan dalam berbagai mata pelajaran berdasarkan hasil analisis terdapat keterkaitan materi pelajaran dengan potensi lokal yang diselenggarakan di suatu daerah tertentu tempat siswa atau sekolah berada (Budiarto et al., 2020).

\section{METODE PENELITIAN Desain Penelitian}

Penelitian pengembangan yang dirancang untuk menghasilkan produk merupakan jenis penelitian ini. Produk yang dikembangkan berupa modul pembelajaran fisika SMA pokok bahasan fluida statis berbasis potensi lokal pada Waduk Lecari Banyuwangi. Penelitian ini dilaksanakan di kelas XI SMAN 1 Gambiran pada semester ganjil tahun ajaran 2020/2021.

Penelitian ini termasuk dalam Research and Development (R\&D). Desain penelitian pengembangan modul pembelajaran fisika SMA berbasis potensi lokal pada Waduk Lecari menggunakan model pengembangan four-D. Model pengembangan ini terdiri dari empat tahap yaitu, 1) tahap define (pendefinisian), 2) tahap design (perancangan), 3) tahap develop (pengembangan), dan 4) tahap disseminate (penyebaran). Alasan memilih model pengembangan ini karena tepat dimanfaatkan sebagai rancangan untuk mengembangkan perangkat pembelajaran seperti modul, memiliki uraian yang teratur dan lengkap, dalam prosesnya melibatkan evaluasi dari para ahli, sehingga sebelum diterapkan di lapangan, perangkat pembelajaran telah dilakukan perbaikan berdasarkan evaluasi dari para ahli. Validasi

Sebelum di uji cobakan di lapangan penting dilakukan penilaian terhadap produk yang dikembangkan. Penilaian yang dilakukan berupa validasi isi. Instrumen yang digunakan untuk validasi adalah lembar validasi. Pada tahap ini menggunakan teknik analisis deskriptif kuantitatif. Analisis ini digunakan untuk memproses data yang didapat dari lembar validasi ahli dalam bentuk rerata nilai indikator. Langkah-langkah untuk menentukan rerata nilai untuk setiap aspek validasi adalah sebagai berikut:

a) Melakukan rekapitulasi data penilaian melalui nilai rerata total dengan rumus:

$(\tilde{x})=\frac{\text { total skor validator }}{\text { jumlah responden } \times \text { jumlah pertanyaan }}$

b) Menentukan jarak interval dari penilaian sangat baik hingga sangat kurang, dengan skor terendah adalah 1 dan skor tertinggi adalah 5:

Jarak Interval $=\frac{\text { skor tertinggi-skor terendah }}{\text { jumlah } \text { kelas interval }}$

Tabel 1. Klasifikasi Analisis Kevalidan

\begin{tabular}{cl}
\hline Rata- Rata Total & Klasifikasi \\
\hline $1,0 \leq \tilde{x}<1,8$ & Tidak Valid \\
$1,8 \leq \tilde{x}<2,6$ & Kurang Valid \\
$2,6 \leq \tilde{x}<3,4$ & Cukup Valid \\
$3,4 \leq \tilde{x}<4,2$ & Valid \\
$4,2 \leq \tilde{x}<5,0$ & Sangat Valid \\
\hline
\end{tabular}

(Widoyoko, 2013)

\section{Uji Kepraktisan}

Uji coba pengembangan terdapat dua pengukuran yaitu uji efektivitas dan uji kepraktisan. Implementasi modul pembelajaran dilakukan dengan mengujikan modul tersebut di kelas XI MIPA. Populasi kelas tersebut berisi 30 siswa. Setelah dilakukan proses pembelajaran yang menggunakan modul pengembangan, siswa diberikan kuesioner respon. Data yang diambil berupa kritik dan masukan dari siswa mengenai modul tersebut yang dinyatakan dalam skala Likert.

Analisis skala Likert lima interval secara kuantitatif digunakan pada tahap ini. Kuesioner ini terdiri dari pernyataan positif dan pernyataan negatif dengan kriteria penilaian sebagai berikut:

Tabel 2. Kriteria Penilaian Kuesioner

\begin{tabular}{|c|c|c|}
\hline \multirow{2}{*}{ Jawaban } & \multicolumn{2}{|c|}{ Skor } \\
\cline { 2 - 3 } & Positif & Negatif \\
\hline Sangat Setuju & 5 & 1 \\
Setuju & 4 & 2 \\
Kurang Setuju & 3 & 3 \\
Tidak Setuju & 2 & 4 \\
Sangat Tidak Setuju & 1 & 5 \\
\hline
\end{tabular}

Perolehan skor dari jawaban siswa kemudian dirubah ke dalam bentuk persentase. Rumus untuk menentukan persentase kepraktisan menurut Sa'dun Akbar adalah sebagai berikut:

Keterangan:

$$
P=\frac{T S e}{T S h} \times 100 \%
$$

$P \quad$ : nilai persentase 
TSe : total skor jawaban siswa

TSh : total skor maksimal yang diharapkan

Tabel 3. Klasifikasi Kepraktisan Modul

\begin{tabular}{cc}
\hline Kriteria Kepraktisan & Klasifikasi \\
\hline $81 \%-100 \%$ & Sangat Praktis \\
$61 \%-80 \%$ & Praktis \\
$41 \%-60 \%$ & Kurang Praktis \\
$21 \%-40 \%$ & Tidak Praktis \\
$0 \%-20 \%$ & Sangat Tidak Praktis \\
\hline
\end{tabular}

\section{Uji Efektivitas}

(Akbar, 2016)

Tingkat efektivitas penggunaan modul dapat diketahui melalui hasil belajar siswa yang ditinjau dari persentase ketuntasan klasikal. Kriteria Ketuntasan Minimum (KKM) yang ditentukan oleh SMAN 1 Gambiran yaitu 75 dari skor maksimum 100. Ketuntasan individu adalah setiap siswa dikatakan tuntas belajarnya jika mencapai nilai Kriteria Ketuntasan Minimal yaitu $\geq 75$ dari skor maksimal 100 , dan jika dalam kelas tersebut terdapat $\geq 85 \%$ siswa yang telah tuntas, maka kelas tersebut dinyatakan mencapai ketuntasan klasikal.

$\mathrm{KBK}=\frac{\text { Banyaknya siswa yang tuntas belajar }}{\text { Banyak siswa seluruhnya }} \times 100 \%$

Tabel 4. Kriteria Tingkat Ketuntasan Hasil Belajar Siswa

\begin{tabular}{cc}
\hline $\begin{array}{c}\text { Persentase Hasil } \\
\text { Belajar }\end{array}$ & Kriteria Hasil Belajar \\
\hline $\mathrm{T} \geq 80 \%$ & Sangat Baik \\
$70 \% \leq \mathrm{T}<80 \%$ & Baik \\
$60 \% \leq \mathrm{T}<70 \%$ & Cukup Baik \\
$50 \% \leq \mathrm{T}<60 \%$ & Kurang \\
$\mathrm{T}<50 \%$ & Kurang Sekali \\
\hline
\end{tabular}

(Trianto, 2011)

\section{HASIL DAN PEMBAHASAN}

Produk pengembangan pada riset ini adalah modul pembelajaran fisika SMA berbasis potensi lokal pada Waduk Lecari dengan tujuan hasil belajar siswa pada materi fluida statis dapat mengalami peningkatan dan melestarikan potensi lokal yang ada pada daerah tersebut dengan subjek penelitian siswa kelas XI MIPA 1 SMA Negeri 1 Gambiran. Halaman sampul modul yang dikembangkan terdiri dari dua bagian yaitu halaman depan dan belakang dengan gambar 2 dimensi waduk atau bendungan yang merupakan contoh penerapan fluida statis. Modul dicetak menggunakan kertas A4 yang terdiri dari 32 halaman, berisikan konsep fluida statis, hukumhukum fluida, gejala kapilaritas, serta viskositas dan hukum Stokes. Halaman sampul depan dan belakang yang dikembangkan memiliki tampilan sebagai berikut.

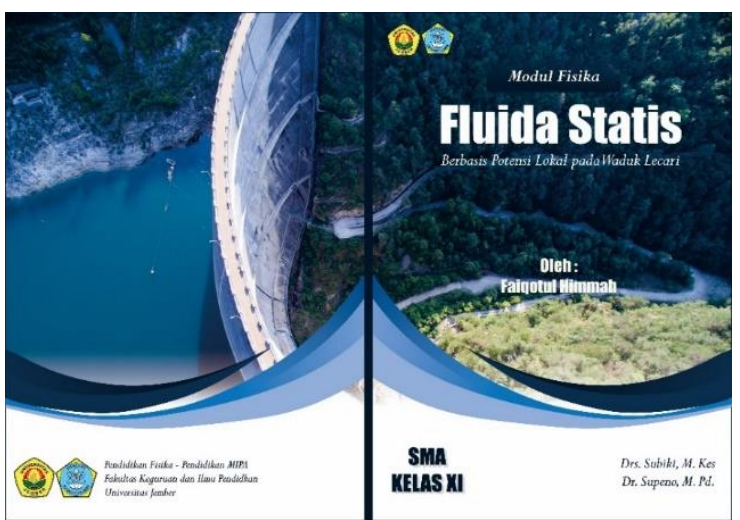

Gambar 1. Tampilan sampul depan dan belakang

\section{Tahap Define}

Pada tahapan define (pendefinisian) terbentuk dari 5 langkah yaitu, langkah pertama analisis awal-akhir, adalah metode untuk mengetahui problematika yang akan dihadapi ketika pelaksanakan proses pembelajaran. Pengamatan secara langsung digunakan untuk mengidentifikasi permasalahan di kelas. Hasil dari pengamatan ditemukan beberapa permasalahan yang dihadapi dalam kegiatan belajar mengajar di masa pembelajaran dalam jaringan (daring). Permasalahan-permasalahan tersebut adalah belum adanya media pembelajaran mandiri untuk siswa pada masa pandemi ini, proses pembelajaran masih terpaku pada guru pengampu, kurangnya pemahaman siswa terhadap materi, belum adanya bahan ajar yang memanfaatkan pada potensi lokal yang ada.

Langkah kedua yaitu analisis siswa, pada dasanya usia rata-rata siswa kelas sebelas SMA berkisar pada 16-17 tahun. Tahap perkembangan kognitif pada usia ini ditandai dengan mampu berpikir abstrak, sistematik dan mampu mengungkapkan hipotesis. Pada usia inilah siswa memiliki kemampuan berpikir alternatif sehingga kemungkinan memecahkan suatu masalah menjadi lebih beragam. Pembelajaran yang masih terpaku pada guru pengampu akan menghambat perkembangan kognitif siswa pada kisaran usia tersebut, karena siswa tidak dapat belajar secara mandiri dan hanya mengandalkan guru ketika proses pembelajaran berlangsung.

Langkah ketiga yaitu analisis tugas, kegiatan mengidentifikasi keterampilan pokok siswa yang dibutuhkan dalam pembelajaran. Pokok bahasan yang akan dibahas dalam modul pembelajaran fisika ini adalah pokok bahasan fluida statis. Sesuai dengan Standar Kompetensi (SK) dan Kompetensi Dasar (KD) dalam Kurikulum 2013.

Langkah keempat yaitu analisis konsep, dalam proses pembelajaran merekognisi konsep utama penting dilakukan. Peneliti 
memilih materi pada pokok bahasan fluida statis dalam modul pengembangan pembelajaran fisika SMA berbasis potensi lokal pada Waduk Lecari. Pokok bahasan ini masuk kedalam daftar pokok bahasan semester ganjil di silabus Kurikulum 2013. Waduk lecari dipilih sebagai penerapan pokok bahasan fluida statis, karena mengandung prinsip-prinsip fluida dengan harapan, siswa mampu memahami pokok bahasan fluida statis melalui penerapan pada lingkungan sekitar.

Waduk Lecari yang terletak di Dusun Sumberejo, Desa Wringinagung, Kecamatan Gambiran, dibangun pada tahun 1970-an dengan kondisi waduk saat ini begitu terawat. Tujuan dibangunnya waduk ini dikarenakan ketika musim kemarau daerah hilir selalu kekeringan dan tidak mendapat pasokan air yang cukup, selain itu ketika hujan deras datang, air sungai selalu meluap hingga menutupi jalan dan menggenangi pemukiman warga. Waduk Lecari ini membendung sungai yang berada di perbatasan antara Desa Wringinagung dan Desa Tegalsari dan merupakan cabang sungai Kali Setail yang kemudian dikembangkan menjadi salah satu destinasi wisata yang dikelola oleh warga sekitar sejak tahun 2019. Waduk ini memiliki kedalaman sekitar $7 \mathrm{~m}$ dengan ketebalan pinggiran waduk sekitar $34 \mathrm{~cm}$. Di tahap awal pembangunan wisata ini, dibangun keramba berisi ikan koi yang disediakan untuk edukasi anak-anak dan sampai saat ini masih dipelihara dengan baik serta ditambah jenis ikan lain yaitu ikan nila dan ikan patin. Konsep-konsep fluida statis yang dapat diambil dari waduk ini terdapat pada subbab tekanan hidrostatis, hukum utama hidrostatis, tegangan permukaan, hukum Archimedes, gejala kapilaritas, serta viskositas dan hukum Stokes.

Langkah kelima yang didasarkan pada Standar Kompetensi dan Kompetensi Dasar yang ada dalam Kurikulum 2013 yaitu spesifikasi tujuan pembelajaran.

\section{Tahap Design}

Hasil dari tahap ini adalah draft modul pokok bahasan fluida statis yang terdiri dari beberapa sub bab yaitu, hukum utama Hidrostatis, hukum Pascal, hukum Archimedes, gejala kapilaritas, serta viskositas dan hukum Stokes.

a. Bagian awal

1. Halaman judul (cover), memuat identitas modul berbasis potensi lokal pada Waduk Lecari, jenjang pendidikan adalah SMA kelas XI dan nama penulis dicantumkan.

2. Kata pengantar.

3. Petunjuk penggunaan modul.
4. Daftar isi.

5. Peta konsep.

6. Standar Kompetensi dan Kompetensi Dasar yang sesuai dengan kurikulum 2013.

7. Tujuan pembelajaran.

b. Bagian isi, berisi pengenalan Waduk Lecari, sekilas info berisi fakta menarik terkait materi yang dibahas, uji wawasan, fakta ilmuwan, contoh soal yang diadaptasi dari peristiwa yang terjadi di Waduk Lecari, latihan, ringkasan materi dan tes formatif.

c. Bagian akhir, berisikan lembar kosong yang bisa digunakan untuk catatan, halaman kunci jawaban, halaman daftar pustaka dan halaman sampul belakang modul.

\section{Tahap Develop}

Perolehan data validasi ahli didapat dari 2 ahli dibidangnya yang merupakan dosen dari program studi Pendidikan Fisika dan 1 validasi pengguna yaitu guru pengampu fisika di SMAN 1 Gambiran. Hasil validasi oleh tiga validator terhadap modul pembelajaran dapat dilihat pada Tabel 5. di bawah.

Tabel 5. Hasil Validasi Modul

\begin{tabular}{|c|c|c|c|c|c|}
\hline \multirow{2}{*}{ Komponen } & \multicolumn{2}{|c|}{ Validator } & \multirow{2}{*}{$\begin{array}{l}\text { Rata- } \\
\text { rata }\end{array}$} & \multirow{2}{*}{$\%$} & \multirow{2}{*}{ Klasifikasi } \\
\hline & $\mathrm{Va}$ & $V p$ & & & \\
\hline Modul & 4,54 & 3,96 & 4,25 & $85 \%$ & $\begin{array}{l}\text { Sangat } \\
\text { Valid }\end{array}$ \\
\hline
\end{tabular}

Berdasarkan hasil rerata dari tahapan validasi ahli dan validasi pengguna diatas, dapat diketahui bahwa modul pembelajaran fisika SMA berbasis potensi lokal pada Waduk Lecari diklasifikasikan sangat valid dengan skor rerata sebesar 4,25 dan ditunjukkan dengan persentase sebesar $85 \%$. Langkah selanjutnya yaitu menerapkan modul pembelajaran yang telah dikembangkan berbasis potensi lokal pada Waduk Lecari kepada kelas yang telah dipilih oleh peneliti.

Uji kepraktisan dilaksanakan dengan penyebaran lembar kuesioner respon siswa setelah proses pembelajaran dilakukan yang terdiri dari pernyataan positif dan negatif. Aspek-aspek yang dinilai dalam kepraktisan modul pembelajaran yaitu, kemudahan penggunaan, daya tarik, dan efisiensi yang ditunjukkan oleh beberapa indikator. Hasil uji kepraktisan modul pembelajaran fisika berbasis potensi lokal pada Waduk Lecari dapat diperhatikan melalui tabel di bawah:

Tabel 6. Hasil Uji Kepraktisan

\begin{tabular}{lllcl}
\hline \multicolumn{1}{c}{ Aspek } & TSe & TSh & $\%$ & Klasifikasi \\
\hline $\begin{array}{l}\text { Kemudahan } \\
\text { penggunaan }\end{array}$ & 895 & 1.200 & $74,58 \%$ & Praktis \\
\hline Daya Tarik & 641 & 900 & $71,2 \%$ & Praktis \\
\hline
\end{tabular}




\begin{tabular}{lllll}
\hline Efisiensi & 122 & 150 & $81,3 \%$ & $\begin{array}{l}\text { Sangat } \\
\text { Praktis }\end{array}$ \\
\hline Rata-rata total & & & $75,6 \%$ & Praktis \\
\hline
\end{tabular}

Secara keseluruhan modul pembelajaran fisika pokok bahasan fluida statis berbasis potensi lokal pada Waduk Lecari mencapai kategori praktis dengan persentase sebesar $73,7 \%$. Selain itu, modul ini dikatakan praktis karena mudah digunakan dan efisien untuk melakukan pembelajaran secara mandiri saat pandemi COVID-19 saat ini, dimana dampak pada bidang pendidikan sangat terasa, seperti pembatasan jam untuk tiap mata pelajaran dan penyesuaian dengan pembelajaran online. Contoh dan latihan soal pada modul ini juga membuat siswa lebih memahami dan mendorong rasa ingin tahu pada materi fluida statis. Penerapan potensi lokal yaitu Waduk Lecari dalam modul ini sangat membantu siswa lebih mudah untuk memecahkan permasalahan tentang fluida statis sekaligus untuk mengenalkan dan melestarikan potensi yang ada di Gambiran.

Pengambilan data efektivitas modul dilakukan dengan pemberian tes tulis setelah pelaksanaan uji coba produk. Tes yang digunakan tersusun dari 5 soal pilihan ganda yang mengandung indikator yang disesuaikan dengan pemberian materi pelajaran. Tes ini dilakukan pada pertemuan ketiga setelah kegiatan pembelajaran menggunakan modul yang telah dikembangkan. Analisis efektivitas modul pengembangan dibuktikan dari ketuntasan klasikal yang didapat melalui perbandingan hasil tes dengan nilai ketuntasan yang telah ditentukan oleh pihak SMAN 1 Gambiran.

Tabel 7. Hasil Analisis Lembar Tes

\begin{tabular}{lcc}
\hline \multirow{2}{*}{ Indikator } & \multicolumn{2}{c}{ Jumlah Siswa } \\
\cline { 2 - 3 } & Tuntas & Tidak Tuntas \\
\hline K. Individual & 26 & 4 \\
\hline KBK & \multicolumn{2}{c}{$86,67 \%$} \\
\hline
\end{tabular}

Modul dikatakan efektif apabila mampu memberikan efek yang baik terhadap hasil belajar siswa. Dapat dilihat pada Tabel 7 . memperlihatkan bahwa kelas XI MIPA 1 telah tuntas secara klasikal dengan persentasi sebesar $86,67 \%$ dengan 26 siswa dinyatakan tuntas individu. Hal ini membuktikan bahwa modul pembelajaran fisika pokok bahasan fluida statis berbasis potensi lokal pada Waduk Lecari efektif untuk digunakan karena mampu memberikan dampak yang baik pada siswa, dapat membantu pembelajaran fisika, dan mampu mengenalkan siswa untuk lebih mengenal lingkungan sekitarnya dari pandangan sains.

\section{Tahap Disseminate}

Modul pembelajaran fisika SMA berbasis potensi lokal pada Waduk Lecari yang sudah melewati berbagai tahapan pengembangan dan dibuktikan layak digunakan sebagai media pembelajaran, kemudian disebarkan secara terbatas di kelas XI MIPA SMAN 1 Gambiran.

\section{SIMPULAN DAN SARAN}

Modul pembelajaran fisika SMA pokok bahasan fluida statis berbasis potensi lokal pada Waduk Lecari dapat disimpulkan sangat valid, praktis, dan efektif untuk digunakan sebagai bahan ajar pada materi fluida statis serta dapat membantu siswa mencapai kriteria ketuntasan yang telah ditetapkan oleh SMAN 1 Gambiran. Modul yang dikembangkan memiliki beberapa keunggulan yaitu, 1) penyertaan gambar potensi lokal sebagai pendukung pembelajaran, 2) pemahaman konsep pada tes formatif maupun contoh soal sudah tergolong dalam HOTS (High Order Thinking Skills), 3) memaksimalkan pemanfaatan potensi lokal sebagai sumber belajar, 4) dilengkapi dengan tata cara perhitungan tingkat penguasaan, sehingga siswa mampu mengetahui penguasaan materi yang telah dipelajari.

Peneliti berharap bagi guru pengampu dapat menerapkan potensi lokal pada materi atau bab lainnya untuk meningkatkan minat dan rasa ingin tahu siswa terhadap materi dan potensi lokal itu sendiri. Selain itu, agar siswa mampu mencapai ketuntasan individual sesuai dengan yang telah ditetapkan sekolah. Penggunaan modul pembelajaran berbasis potensi lokal diperlukan pemahaman yang mendalam pada konsep materi itu sendiri dan pengaplikasiannya, juga diharapkan untuk peneliti lain dapat mengembangkan dengan metode yang lebih baik lagi seperti dalam bentuk e-book maupun yang lain. Lembaga pendidikan diharapkan dapat mendukung dan mencari metode yang paling efektif dalam menerapkan pembelajaran daring seperti menggunakan modul berbasis potensi lokal maupun bahan ajar yang dapat membuat siswa mampu belajar mandiri di masa pandemic seperti saat ini.

\section{UCAPAN TERIMAKASIH}

Ucapan terima kasih peneliti tujukan kepada dosen-dosen pembimbing Pendidikan Fisika Universitas Jember. Selain itu peneliti sampaikan terima kasih kepadda seluruh warga SMAN 1 Gambiran karena telah berkenan menerima dan memberikan bantuan kepada peneliti selama penelitian berlangsung, serta kepada seluruh pihak yang telah membantu kelancaran penelitian ini. 


\section{DAFTAR RUJUKAN}

Agustin, P. U. W., Wahyuni, S., \& Bachtiar, R. W. (2018). Pengembangan Modul Fisika Berbasis Potensi Lokal "Batik Lumbung Dan Tahu Tamanan" Untuk Siswa Sma Di Kecamatan Tamanan Bondowoso (Materi Suhu Dan Kalor). Jurnal Pembelajaran Fisika, 7(1), 62. https://doi.org/10.19184/jpf.v7i1.7226

Akbar, S. (2016). Instrumen Perangkat Pembelajaran. PT. Remaja Rosdakarya.

Budiarto, M. K., Joebagio, H., \& Sudiyanto. (2020). Integration of Interactive Multimedia with Local Potential as a Learning Innovation in Digital Era. 421(Icalc 2019), 336-345. https://doi.org/10.2991/assehr.k.200323.0 40

Daryanto. (2013). Menyusun Modul Bahan Ajar untuk Persiapan Guru dalam Mengajar. Gava Media.

Depdiknas. (2008). Teknik Penyusunan Modul. $1-14$.

Fitrianingrum, N., Sunarno, W., \& Harjunowibowo, D. (2013). Analisis Miskonsepsi Gerak Melingkar Pada Buku Sekolah Elektronik (Bse) Fisika Sma Kelas X Semester I. Jurnal Pendidikan Fisika, 1(1), 73-80.

Hamalik, O. (2006). Proses Belajar Mengajar. PT. Bumi Aksara.

Hernawan, A. H. (2008). Makna Ketuntasan Dalam Belajar. Majalah IImiah Pembelajaran, 4(2), 1-15.

Mundilarto. (2010). Penilaian Hasil Belajar Fisika. UNY Press.

Saway, V. L. (2004). Global Responsibility and Local Knowledge Systems. Bridging Scales and Epistemologies: A Millennium Assessment Paper of the Millennium Ecosystem Assessment Conference, 110.

http://www.millenniumassessment.org/do cuments/bridging/papers/saway.datu.pdf

Sudjana, N., \& Rivai, A. (2007). Media Pengajaran. Sinar Baru Algesindo.

Sukmawati, R., Ertikanto, C., \& Suyatna, A. (2016). Efektivitas Modul Pembelajaran Fisika Berbasis Inkuiri Terbimbing Ditinjau Dari Kemampuan Berfikir Kritis. Jurnal Pembelajaran Fisika, 4(3).

Trianto. (2011). Model-model Pembelajaran Inovatif Berorientasi Konstruktivistik. Prestasi Pustaka Publisher.

Utomo, T., \& Ruijter, K. (1991). Peningkatan dan Pengembangan Pendidikan. Gramedia Pustaka Utama.

Widoyoko, S. E. P. (2013). Teknik Penyusunan Instrumen Penelitian. Pustaka Pelajar. 